\title{
Spatial Design
}

National Cancer Institute

\section{Source}

National Cancer Institute. Spatial Design. NCI Thesaurus. Code C41149.

Refers to the ways in which objects or bodies are placed in space and in relation to each other. 